On the other hand, such colloids as gelatin have not indicated any regular pattern when examined by X-rays. A fully developed network of oriented molecules such as Dr. Sheppard describes should give indications analogous to a crystalline structure when thus examined. This X-ray method of investigation is being applied in another department of the University of Bristol to the various forms of soap solutions. It is hoped also to obtain fresh light on the problem by the experiments now being carried out by Miss Laing on the conduction of continuous current through soap jellies.

Dr. Sheppard's demand that any "consistent" theory of colloids should permit of the deduction of all the physical properties from the chemical formula alone, appears to over-estimate the extent to which the manifold physical properties of gold and silver sols of different degrees of subdivision and colour can be deduced merely from the knowledge of the chemical formulæ of the metals. In conclusion, I think his idea is at present too vague and not sufficiently in accord with such facts as those mentioned to be likely to prove more fruitful than the one it seeks to feplace, incomplete as the latter is in the absence of further experiment.

The Chemical Department, University of Bristol, February 24

\section{The Production of Living Clavellina Zooids in Winter by Experiment.}

IN a recent publication ("Sea-temperature, Breeding, and Distribution in Marine Animals," Journ. Mar. Biol. Assoc., vol. xii., No. 2, p. 35r) the present writer showed that there was every reason to believe that the hibernation phenomena in many marine animals are purely temperature effects. In order to test this view the positions of sixteen good colonies of the beautiful Ascidian. Clavellina lepadiformis were marked on September I, I920, on the wooden piles of the West Wharf, Great Western Docks, Millbay, Plymouth. This Ascidian usually appears on these piles about the end of May and dies down about the end of October, and has never been recorded in winter. On September $\mathrm{I}_{5}$ and 30 the piles were again visited and a record was made of those colonies which had survived the marking. The positions of the colonies were found to be shown effectively by three long wire nails driven into the piles on the outside of the colonies at the apices of imaginary triangles. On February 23 last the laboratory collector, $\mathrm{Mr}$. Wm. Searle, who assisted in the marking of the colonies, visited the piles at the West Wharf and took careful scrapings between the nails marking the positions where Clavellina colonies were seen in September, I920.

The material obtained remained in the collecting honey-jars on the floor of the laboratory until 8 p.m. of February 24. It was then examined, and anything like a resting stage of an Ascidian was picked out, cleaned a little, and transferred to clean water in a glass dish. On February 25 at noon the material was put into a warm room at a temperature of about $61^{\circ} \mathrm{F}$., and distributed in a number of finger-bowls in ordinary tank-water passed through a Berkefeldt filter.

Little attention was given to the bowls beyond changing the water on February 28, until March $\mathrm{I}$, when a distinct Clavellina zooid was found in one dish and a bud in another. From that date onwards the number of zooids and buds has increased, and at the latest observation made on March 8 there were NO. $268 \mathrm{I}$, VOL. IO7] twelve living zooids or well-developed buds and two well-developed zooids had been preserved. From the beginning of the experiment to March I the temperature did not fall below $60^{\circ} \mathrm{F}$., and from an inspection of the thermograph records the mean temperature of the room is seen to be very nearly $6 \mathrm{I}^{\circ} \mathrm{F}$.; probably the mean temperature of the water in the dishes would be slightly lower. Since March I the mean temperature of the room and water has been slightly higher.

It is therefore highly probable that the awakening of Clavellina from the resting stage is a pure tem. perature effect. In this experiment tank-water was deliberately used, and it is considered highly improbable that this water can be regarded as biologically better than the water now surrounding the sleeping stages of Clavellina in the sea. There remains, therefore, only the presence or absence of some recondite chemical complex in the water as a possible factor in aiding in the awakening of this Ascidian. The existence of such a complex is, however, not regarded as probable.

Driesch has shown that Clavellina regenerates lost parts with facility, and that starving or foul water will also cause this Ascidian to absorb all its organs and pass into an undifferentiated condition. It would appear, however, that none of these factors operate during the period of hibernation, since the water at the West Wharf is undoubtedly more foul during the period when Clavellina flourishes than when it passes into and remains in the resting condition, and similar Ascidians in the same locality feed and grow during the winter. Other forms which feed in the same way, and probably on the same kinds of food, as Clavellina also flourish and grow in the same situation in winter.

It would therefore seem that variations in temperature are the normal stimuli for development and differentiation in Clavellina, and the determination of the actual point in temperature at which these changes occur should afford a useful clue in attacking the question of the underlying chemico-physical changes.

The winter resting stages of Clavellina are very simple bodies; they are flattened expansions of transparent gelatinous material (tunicin) with a mammillated surface containing a core of opaque yellow tissue - apparently undifferentiated - which shows mammillations corresponding to those in the gelatinous coat. In the development of the zooids the mammillations swell and a core of tissue extends into the swelling. The bud thus formed increases in size and differentiates into the zooid.

The Laboratory. The Hoe, Plymouth, March 9.

The Elementary Particle of Positive Electricity.

REGARDING the suggestions for the name of the nydrogen nucleus made by Prof. Soddy (NATure, December 16, I920, p. 502) and Dr. Prideaux (Nature, December 30, I920, p. 567), it would seem to be better to use the term "hydron" instead of "hydrion," as being shorter and more euphonious.

It may be recalled that the late Lord Kelvin used himself, and tried in vain to induce others to use, the term "electrion" instead of "electron." At this late date it seems quite unnecessary to insist on the retention of the extra svllable simply to have the word "ion" retained in the longer term unless for the sake of euphony, as in "thermion."

AndREW H. Patterson.

University of North Carolina, February I9. 